\title{
Współczesny literacki język prekmurski (casus Porabja)
}

\begin{abstract}
Kowalski Paweł, Współczesny literacki język prekmurski (casus Porabja) (Modern Literary Prekmurian Language: the Case of Porabje). „Poznańskie Studia Slawistyczne” 8. Poznań 2015. Publishing House of the Poznań Society for the Advancement of the Arts and Sciences, pp. 93-105. ISSN 2084-3011.
\end{abstract}

The aim of the paper is to present the modern Prekmurian language that is nowadays used in Porabje. Porabje, located in Hungary, is a part of the bigger historical region named Prekmurje. While the Prekmurje was divided between Jugoslavia and Hungary after the first world war, one could see that the role of the Prekmurian language in Porabje was marginalized. Now it is used only in a few language areas. The consideration leads to some terminological conclusions.

Keywords: history of language; literary language; Porabje; Prekmurian language; Raba Slovene

Zagadnienia dotyczące mniejszości narodowych od dawna interesują wielu badaczy różnych dyscyplin naukowych. W dobie postępującej globalizacji - rozumianej jako proces integracji i współzależności państw, społeczeństw, a także kultur - badania grup mniejszościowych stanowią cenne źródło wiedzy o języku, historii i kulturze danej wspólnoty. Przyczyniają się do zachowania jej istnienia w podlegającej ciągłym przemianom rzeczywistości. Obecnie w świecie słowiańskim zaobserwować można tendencje do wyodrębniania się nowych etnolektów, które wiążą się z dynamicznym charakterem procesów społecznych. Powszechnie podnoszone jest prawo do wyrażania świadomości grupowych, mikrogrupowych, mikronarodowych. Weryfikacji poddaje się czynniki konstytuujące takie wspólnoty, pośród których istotny na obszarze Słowiańszczyzny jest język. 


\section{2.}

Przedmiotem artykułu jest literacki język prekmurski, używany na terenie Porabja przez słoweńską mniejszość narodową tzw. Słoweńców porabskich. Zamieszkują oni kilka wsi w południowo-zachodniej części Węgier w komitacie Vas. Porabje liczy jedynie 94 kilometry kwadratowe. Nazwa regionu pochodzi od jednego z dopływów Dunaju - rzeki Raby, której źródła znajdują się w Alpach Styryjskich. Do końca I wojny światowej terytorium Porabja stanowiło integralną część większego słoweńskiego regionu Prekmurje - dziś najbardziej na północny wschód wysuniętego obszaru Republiki Słowenii. Na mocy traktatu w Trianon z 1920 roku Porabje, oddzielone od Prekmurja, pozostało w granicach państwa węgierskiego. Od tego czasu - przez cały niemal XX wiek - rozwijało się w izolacji od pozostałych ziem słoweńskich.

Słoweńcy porabscy w mowie, oprócz dominującego współcześnie języka węgierskiego, używają dwóch gwar: sztefanowskiej i górnosenickiej. W piśmiennictwie natomiast stosowany jest literacki język prekmurski we współczesnej postaci oparty na gwarach porabskich - i literacki język słoweński, używany na terenie Republiki Słowenii. Nazwa języka prekmurskiego jest przeniesieniem nazwy łacińskiej regionu Transmuranus obszaru leżącego „za Murą" - i upowszechniła się po 1919 roku. Jeszcze w XIX wieku język prekmurski był nazywany, w opozycji do centralnosłoweńskiego wariantu literackiego (kranjščina), językiem słoweńskim (slovenski jezik), niekiedy też starosłoweńskim (staro slovenski jezik).

\section{3.}

Losy powstawania normy literackiej są zagadnieniem złożonym, a jej opis w ujęciu diachronicznym polega na przedstawieniu poszczególnych faz kształtowania się takiej normy. Zazwyczaj pojęcie ,języka literackiego" stosowane jest do zdefiniowania znormalizowanej (ponaddialektalnej) odmiany. Niekiedy używa się nazwy ,język kulturalny” lub „ogólnonarodowy", choć - co należy podkreślić - te pojęcia nie zawsze mogą być stosowane wymiennie, ich desygnaty bowiem nie pokrywają się. Najczęściej mianem języka literackiego określa się jedynie znormalizowaną odmianę 
pisaną języka ogólnonarodowego (Perlin 1986: 9). W przypadku literatur regionalnych, które na osi: centrum - peryferie funkcjonują na obrzeżach przestrzeni zarezerwowanej dla literatur narodowych, podstawę stanowi pewna norma dialektalna, charakterystyczna jedynie dla danego regionu.

W terminologii słoweńskiej obok pojęcia knjižni jezik (język literacki) występuje pojęcie pokrajinski knjižni jezik (regionalny język literacki), który Matej Šekli definiuje następująco:

Pokrajinski knjižni jezik lahko opredelimo v razmerju do jezika kot genetske jezikovne pojavnosti ter do knjižnega jezika kot družbene jezikovne pojavnosti. Tako bi pokrajinski knjižni jezik lahko definirali kot konkretni, tj. sistemski, neorganski idiom, ki na nekem zemljepisno omejenem območju znotraj jezika ali dela jezika opravlja družbeno sporazumevalno vlogo namesto krovnega knjižnega jezika (...). Od krovnega knjižnega jezika pa se razlikuje predvsem po zmanjšani družbeni vlogi, saj zaradi zemljepisne omejenosti svojega delovanja lahko opravlja kvečjemu pokrajinsko povezovalno in pokrajinsko predstavniško vlogo, kar se zrcali tudi v njegovi okrnjeni funkcijskozvrstni razčlenjenosti (Šekli 2004: 48).

Autor podkreśla funkcję komunikacyjną języka regionalnego, wskazując na jego ograniczenia terytorialne w porównaniu do ogólnonarodowego języka literackiego. Zinka Zorko zauważa tendencję do tworzenia się na Porabju ponaddialektalnej (ponadgwarowej) normy: „Porabščina se kot slovenski porabski knjižni jezik na vseh jezikovnih ravninah dviga nad narečje" (Zorko 2005: 54). Język Słoweńców porabskich nazywa porabszczyzną lub prekmurszczyzną. Proces tworzenia się normy standardowej na Porabju nie przebiega jednak w sposób usystematyzowany.

W swojej monografii Aleksandr Dmitrijewicz Duliczenko przedstawia opis typologiczny dwunastu literackich mikrojęzyków słowiańskich ${ }^{1}$, definiując pojęcie literackiego mikrojęzyka jako: „образования, которые обладают письменной формой и функционируют в рамках более или менее организованного литературно-языкового процесса, формирующего и реализующего грамматические и лексические нормы самим применением такого языка в различных сферах жизни" (Дуличенко 2003: 34). Autor dzieli mikrojęzyki słowiańskie na wyspowe - do nich zalicza takie, które zostały znormalizowane oraz przejawiają etapy

${ }^{1}$ Pod koniec XX wieku liczba literackich mikrojęzyków słowiańskich zwiększyła się do piętnastu (Дуличенко 2003: 35). 
kodyfikacji - i peryferyjne (regionalne), charakteryzujące się swobodną normą (Дуличенко 2003: 35). Język prekmurski w swojej klasyfikacji Duliczenko określa jako peryferyjny mikrojęzyk literacki.

\section{4.}

Ogląd współczesnej sytuacji języka prekmurskiego na Porabju nie jest możliwy bez perspektywy diachronicznej, uwzględnienia szerszego tła historycznego, dlatego w dalszej części niniejszego artykułu zostaną nakreślone dzieje tworzenia się języków literackich na ziemiach słoweńskich.

Tradycja piśmiennictwa porabskiego wpisuje się w nurt słoweńskiej literatury regionalnej, będąc częścią bogatej prekmurskiej spuścizny literackiej, której okres największego rozkwitu przypadł na wiek XVIII i początek wieku XIX. Na obszarze słoweńskim w przeciągu kilku stuleci występowały trzy warianty literackie języka słoweńskiego: norma centralnosłoweńska, związana z obszarem alpejskim i norma wschodniosłoweńska, powstała w kręgu panońskim z dwoma językami literackimi: prekmurskim i wschodniostyryjskim (cf. Jesenšek 2005: 15-30). Język centralnosłoweński był pierwszym słoweńskim językiem literackim, stworzonym przez protestantów już w XVI wieku. Primož Trubar, autor pierwszych książek w tym języku, wykorzystał w swoich dziełach elementy językowe zaczerpnięte z mowy Lublany i rodzinnej wsi Raščicy (Kryzia 2008: 46).

Do X wieku obszar panoński stanowił językową jedność. Żywa była pamięć misji Cyryla i Metodego w Państwie Wielkomorawskim, dzięki której na tym obszarze upowszechnił się pierwszy słowiański język literacki - staro-cerkiewno-słowiański. Rozwój piśmiennictwa w tym języku został zahamowany dopiero, gdy na tereny Panonii wkroczyli Węgrzy. Językiem oficjalnym wykształconych elit duchownych i świeckich stała się łacina, a w późniejszym okresie także niemiecki, węgierski i chorwacki kajkawski. W Prekmurju nie istniały więc warunki sprzyjające powstaniu nowego słowiańskiego języka literackiego. Paralele można odnaleźć wśród innych mniejszości słowiańskich żyjących w granicach monarchii św. Stefana. Pisze o tym Marko Jesenšek: 
Slovaki in prekmurski Slovenci v narodnostno mešani državi vse do 18. stoletja niso mogli razviti svojega knjižnega jezika, saj so slovansko misijonsko delo Cirila in Metoda pregnali iz teh krajev že pred prihodom Madžarov, bogato knjižnojezikovno delo v stari cerkveni slovanščini pa se je moralo umakniti latinski, kasneje tudi nemški in madžarski knjigi (Jesenšek 2000/2001: 297).

Słoweńcy prekmurscy do XVIII wieku używali swojego języka przede wszystkim w mowie. W piśmiennictwie obok łaciny i węgierskiego była stosowana chorwacka kajkawszczyzna, która odgrywała istotną rolę na całym obszarze Prekmurja. Szerzeniu się jej wpływów sprzyjała reformacja (cf. m.in. Jembrih 2005: 193-203). Założenie drukarni w 1572 roku w Nedelišciu koło Čakovca przez Juraja Zrinskiego spowodowało, że możliwe było drukowanie ksiąg chorwackich na dużą skalę (Oczkowa 2006: 143). Docierały one również do Prekmurja, w wyniku czego kajkawskie elementy językowe mieszały się z prekmurskimi cechami dialektalnymi. Zjawisko to śledzić można na przykładzie pierwszych prekmurskich pieśni religijnych, spisanych w XVI i XVII wieku.

Najstarszym zachowanym prekmurskim zabytkiem rękopiśmiennym jest Martijanska pesmarica I, napisana najprawdopodobniej jeszcze w XVI wieku. Z tego też okresu pochodzi Martijanska pogodba. Martijanska pesmarica II - jest zabytkiem późniejszym, z roku 1756, i została wydrukowana po pierwszych prekmurskich protestanckich książkach, wydanych w początkach XVIII wieku. Najstarsze zachowane zabytki piśmiennicze o wyraźnych już cechach prekmurskich nie przyczyniły się jednak do ukonstytuowania literackiego języka prekmurskiego. Ukształtował się on dopiero w połowie XVIII wieku. Za podstawę języka literackiego Słoweńców prekmurskich posłużył dialekt prekmurski, na który składają się trzy grupy gwarowe: raweńska, dolińska i gorycka. Różni je wiele stosunkowo młodych innowacji prekmurskich, m.in. zaokrąglenie krótkiego i nieakcentowanego $a$ w goryckiej i raweńskiej grupie, zaokrąglenie długiego i akcentowanego $a \mathrm{w}$ grupie dolińskiej, przekształcenie wygłosowego $-t \mathrm{w}-o$ (w grupie goryckiej i raweńskiej) oraz $\mathrm{w}-u$ (w grupie dolińskiej), przejście $j \mathrm{w} d$ ' (w grupie goryckiej i raweńskiej) (Zorko 2005: 47).

Większość pisarzy prekmurskich w XVIII i XIX wieku wywodziła się z kręgów gwarowych raweńskich i goryckich, dlatego też na podstawie cech językowych, charakterystycznych dla tych dwóch grup, próbowano 
stworzyć normę języka prekmurskiego. Istotny wpływ na kształt prekmurszczyzny wywarły dzieła pisarza protestanckiego Števana Küzmiča. Jego przekład Nowego Testamentu z języka greckiego Nouvi zakon ali testamentom goszpodna nasega Jezusa Krisztusa zdaj oprvcs zgrcskoga na sztari szlovenszki jezik obrnyeni po Stefan Kuzmicsi surdanszkom (1771) oraz katechizm ze zbiorem modlitw i pieśni Vore krsztanszke kratki navuk (1754) stanowiły - wraz z pierwszymi książkami protestanckimi (Katechizm Marcina Lutra tłumaczony przez Franca Temlina, Mali szlovenszki katekizmus [1752], ABC knis 'nica [1753]) - podstawę językową, do której odnosili się w późniejszych latach inni pisarze prekmurscy.

Koniec XVIII wieku charakteryzuje rozwój katolickiego piśmiennictwa prekmurskiego. Był to przede wszystkim okres działalności Mikloša Küzmiča. Trzy jego dzieła: Kratka summa velikoga katekizmusa (1780), Szveti evangyeliomi Pouleg Kalendariona i Reda Rimszkoga na Vsze Nedelne, i Szvetesnye z-Obcsinszkoga szvetoga Piszma po zapouvidi Nyih Goszposztva i Naj Visse Postuvanoga Goszpodina Szily Janosa, z-Gonyega Szopora, Szombotelskoga Puspeka, na Sztari Szlovenszki jezik, Po postuvanom Goszpoudi Kuzmics Miklosi obrnyeni (1780) oraz Knjiga molitvena v-steroj sze nahajajo razlocsne ponizne molitvi, z-dvójim pridavekom na haszek szkovenszkoga naroda sz-pobosnim, sztroskom nikih plemenitih dobrocsinitelov Na szvetloszt dana (1783) zostały wydane dzięki pomocy Janosza Szily, węgierskiego biskupa Szombathely, i służyły jako podręczniki szkolne w Prekmurju (Jesenšek 2005: 101).

Działalność piśmiennicza w Prekmurju w pierwszych latach XIX wieku osłabła (Kryzia 2008: 102). Od roku 1833 kontynuował ją Jožef Košič. Jego dzieła, m.in. Kratki navuk vogrszkoga jezika (1833) i Zobrisani Szloven i Szlovenka med Murov i Rabov (1845), miały charakter dydaktyczny i oświeceniowy (Kozar 1994: 89-95). Z powodu silnej madziaryzacji w drugiej połowie XIX wieku protestanci prekmurscy zaniechali działalność piśmienniczą w języku prekmurskim. Jedynymi, którzy podjęli walkę przeciwko polityce węgierskiej, byli katolicy prekmurscy. Nawiązywali kontakty z inteligencją słoweńską z innych regionów w ramach utworzonego Towarzystwa Świętego Hermagorasa i sprowadzali książki do Prekmurja. Napływ tekstów - głównie z sąsiedniej Styrii - powodował osłabienie typowych cech prekmurskich w języku literackim i stopniowe zbliżanie go do standardu kraińskiego (centralnosłoweńskiego). 
Pod koniec XIX wieku jedyną osobą, która pisała i wydawała w języku prekmurskim, był Imre Augustič, redaktor pierwszego czasopisma prekmurskiego „Prijatel”. To dzięki jego działalności język prekmurski zaistniał jako język publicystyki. „Prijatel” był wydawany od roku 1874 - wtedy ukazał się pierwszy próbny zeszyt „Kazajocsi broj” - aż do śmierci jego założyciela w roku 1879. Analiza językowa periodyku, przeprowadzona przez Marka Jesenšeka, wykazała, że Augustič zachował język zbliżony do języka przekładu Nowego Testamentu Küzmiča (cf. m.in. Jesenšek 1999: 327-343). Po śmierci Augustiča działalność piśmiennicza w Prekmurju ustała. Ożyła dopiero w XX wieku, kiedy protestanci prekmurscy zaczęli wydawać w roku 1920 kalendarz Evangeličanski kalendar, a w 1923 roku czasopismo „Düševni list” (Kryzia 2008: 105).

Obok pochodzących z tamtego okresu przekładów dzieł religijnych i twórczości autorskiej pisarzy prekmurskich, mającej w dużej mierze charakter oświatowy, podejmowane były próby opisu języka prekmurskiego. Pierwszą taką pracę stanowiła gramatyka gwary wsi Cankova autorstwa Avgusta Pavla, napisana w języku węgierskim i wydana w 1909 roku w Budapeszcie. Do tej pory nie została jednak przetłumaczona na żaden inny język; być może dlatego niewielu badaczy słoweńskich podjęło się próby jej interpretacji. Zagadnieniem spornym, budzącym kontrowersje wśród pisarzy prekmurskich, był wybór grafii (ortografii) węgierskiej, która zastąpiona została w późniejszym okresie słowiańską ortografią - gajicą (wprowadził ją już w roku 1878 Imre Augustič w czasopiśmie „Prijatel”).

Pod koniec XIX wieku rozpoczął się proces prowadzący do powolnego ograniczania zasięgu języka prekmurskiego, który został sprowadzony do języka peryferyjnego (regionalnego). Dotychczas bowiem prekmurszczyzna była powszechnie używana i mogła rywalizować ze znormalizowanym językiem centralnosłoweńskim. W XX wieku, gdy rola języka prekmurskiego została ograniczona głównie do gwarowych wariantów komunikacyjnych, Porabje stało się miejscem, w którym literacki język prekmurski (stanowiący ponadgwarowy wariant porabski literackiego mikrojęzyka) jest nadal pielęgnowany. W Prekmurju coraz istotniejszą rolę zaczął odgrywać słoweński język literacki. 


\section{5.}

Obecnie na Porabju literacki język prekmurski funkcjonuje w różnym zakresie w kilku sferach: kontakty codzienne, szkoła, stowarzyszenia, informacje, widowiska, życie artystyczno-literackie, publicystyka i Kościół (w ograniczonym zakresie). Brakuje go jednak w sferze usługowej, lecznictwie, w sferze naukowej, w niewielkim wymiarze jest obecny w muzeach. Nie jest także używany w administracji, sądownictwie oraz reprezentacji zagranicznej i kontaktach międzynarodowych (poza rzadkimi kontaktami z rodzimymi użytkownikami języka słoweńskiego z Republiki Słowenii, w takiej sytuacji jednak językiem komunikacji jest najczęściej mówiony wariant literackiego języka słoweńskiego).

Prekmurszczyzna (porabszczyzna) jest stosowana w pierwszym czasopiśmie słoweńskojęzycznym na Porabju, które wydawane jest od 1991 roku pod nazwą „Porabje”. Pomysł czasopisma zrodził się z potrzeby informowania Słoweńców porabskich o wydarzeniach regionalnych w języku ojczystym, a znaczną rolę w jego tworzeniu - na co wskazuje redaktorka pisma Marija Sukič - odegrał założony w 1990 roku Związek Słoweńców na Węgrzech (Zveza Slovencev na Madžarskem): „Edna od najbole pomembni nalog, stero si je Slovenska zveza gordala že pri ustanovitvi, je bila, ka moramo meti slovenske novine, lidge morajo priti do informaciji v maternoj rejči, v domanjoj rejči pa v slovenskoj knjižnoj rejči tö. Tak so se te 1991. leta narodile naše cajtine" (Sukič 2011: 1).

„Porabje” początkowo wydawane było jako dwutygodnik w formie czarno-białej, na sześciu stronach. Dopiero od 2005 roku czasopismo ukazuje się co tydzień na ośmiu kolorowych stronach. Obok artykułów pisanych współczesnym językiem prekmurskim (wykazującym większe lub mniejsze górnosenickie cechy gwarowe) znajdują się w nim teksty w literackim języku słoweńskim, używanym w Republice Słowenii. Valerija Perger podkreśla: ,časopis se ves čas trudi uvajati tudi nadnarečno varianto zapisa in s tem premoščati prepad med narečjem in knjižnim jezikom, ki ga večina Porabcev še vedno doživlja kot tuji jezik" (Perger 2009: 347). Czasopismo służy podtrzymywaniu świadomości językowej Słoweńców porabskich, jednocześnie zaś promuje słoweńszczyznę używaną w Republice Słowenii:

Mi v narečju zdaj za nove stvari uporabljamo izraze iz slovenskega knjižnega jezika. Niti slučajno ne iz madžarščine, kajti mi s tem želimo nekako tudi pomagati ljudem, da 
se navadijo, da se naučijo te nove izraze in če se še velikokrat pojavi kakšen tak izraz, potem v oklepaju mogoče damo madžarski izraz, da bodo točno vedeli, kaj pomeni, da ne bodo narobe uporabljali kakšne besede. Tako, da mislim, da ta časopis služi tudi kot nek učitelj slovenščine, kot nek pouk slovenščine (Sukič 2012).

„Porabje” stanowi swoisty pomost między literackim językiem prekmurskim i literackim językiem słoweńskim - pomiędzy gwarami porabskimi, tzw. prostą mową, i ponaddialektalnym (ponadgwarowym) literackim językiem prekmurskim oraz literackim językiem słoweńskim.

O wielkim sukcesie i promocji języka prekmurskiego, także poza regionem Porabja, można mówić w kontekście ukazania się dwóch powieści Franceka Mukiča (pisarza, publicysty, dziennikarza): Garaboncijaš w 2005 roku i Vtrgnjene korenje w 2010. Ich publikacja możliwa była dzięki wsparciu finansowemu wydawnictwa Franc-Franc, które jest odpowiedzialne za promocję kultury na Porabju, przy znacznym udziale Związku Słoweńców na Węgrzech. W roku 2006 opublikowany został słownik starego języka prekmurskiego autorstwa Vilko Novaka (Novak 2006).

Na Porabju od 1986 roku wydawany jest w języku prekmurskim rocznik o charakterze publicystyczno-literackim pod tytułem „Slovenski koledar”. Każdy z numerów składa się z kilku tematycznych części. W pierwszej z nich: Porabje in Prekmurje inda in gnes (Porabje i Prekmurje kiedyś i dziś), autorzy porabscy dokonują autoprezentacji wspólnoty. Znajdują się w niej także artykuły poświęcone biografiom znanych osób związanych z regionem. W sekcji zatytułowanej Langivanje po svejti (Podróże po świecie) publikowane są relacje z podróży Słoweńców porabskich. Dużą wartość literacką przedstawia część Za duge zimske večeri (Na długie zimowe wieczory), w której ukazują się prace prozatorskie i poetyckie autorów porabskich. Charakter rozrywkowy ma rubryka Nika za smej (Coś do śmiechu), na którą składają się dowcipy, fraszki i krótkie opowiadania. Na końcu każdego numeru znajduje się, podsumowująca wydarzenia minionego roku, sekcja Koledar dogodkov preteklega leta (Kalendarz wydarzeń minionego roku).

Słoweńska mniejszość narodowa na Porabju do roku 1979 miała możliwość słuchania dwudziestopięciominutowej audycji radiowej w węgierskim radiu Györ. Dopiero w 1995 roku Słoweńcy porabscy utworzyli własne radio o nazwie Monošter. Radiostacja do 31 grudnia 2011 roku nadawała jednogodzinną audycję, przeważnie w języku prekmurskim, $\mathrm{w}$ dni powszednie i soboty. Tematy poruszane w audycjach były związane 
przede wszystkim z mniejszością słoweńską na Węgrzech. Program niedzielny trwał dwie godziny, a do studia zapraszano znanych słoweńskich polityków, sportowców, pisarzy i naukowców. W rozmowach ze Słoweńcami z Republiki Słowenii posługiwano się ogólnosłoweńskim wariantem mówionym. Dzięki pomocy finansowej Ministerstwa Sprawiedliwości i Zarządzania Publicznego (Ministrstvo za pravosodje in javno upravo) od stycznia 2012 roku radio Monošter poszerzyło swoją ofertę programową - codziennie od godziny dwunastej do szesnastej nadawane są audycje w językach prekmurskim i słoweńskim.

W telewizji węgierskiej od roku 1992 emitowany jest dwa razy w miesiącu półgodzinny program pod nazwą Slovenski utrinki. Na wizji poruszane są przede wszystkim tematy z życia Słoweńców porabskich, najważniejsze wydarzenia polityczne na Porabju i sąsiednim Prekmurju (Kowalski 2009: 157). W 2009 roku powstał projekt pod nazwą Mura-Raba $T V$, dzięki któremu mieszkańcy Porabja mogą raz w tygodniu oglądać programy dwujęzyczne: w języku prekmurskim i węgierskim, przygotowywane przez telewizję Gotthard.

W 2011 roku została przeprowadzona ankieta dotycząca korzystania z mediów słoweńskich na Porabju (Vajda-Nagy 2011), której wyniki wskazują, że największą grupą odbiorców mediów słoweńskich są osoby starsze, mieszczące się w przedziale wiekowym od sześćdziesięciu do osiemdziesięciu lat. Prawie wszyscy respondenci jednak znacznie częściej korzystają z węgierskiech środków przekazu. Autorka ankiety podkreśla, że słoweńskie media mniejszości porabskiej są tylko uzupełnieniem węgierskich, a ich rola jest marginalna. Niski jest zatem obecnie status języka prekmurskiego jako środka przekazu różnorodnych treści oraz elementu konstytuującego identyfikację Słoweńców porabskich. Nie ma przesłanek, które wskazywałyby, że sytuacja tego języka w najbliższej przyszłości może się poprawić.

6.

Przedstawione powyżej rozważania - mające charakter skrótowy - nasuwają kilka ogólnych wniosków dotyczących współczesnego języka prekmurskiego. Przede wszystkim uwidaczniają się problemy natury nazewniczej. 
Termin język prekmurski odnosi się bowiem do języka literackiego, którego początki datowane są na pierwszą połowę XVIII wieku. W tradycji słoweńskiej na określenie tego języka używany jest także termin „stary literacki język prekmurski” (Novak 2006). Początkowo nazywany był językiem słowiańskim bądź starosłowiańskim, w odróżnieniu od chorwackiej kajkawszczyzny oraz normy centralnosłoweńskiej, w XX wieku zaś określano go jako język prekmurski. Dziś mnogość stosowanych nazw może budzić konsternację, w pracach spotykane są m.in. „literacki język prekmurski”, „regionalny język prekmurski”, „literacki mikrojęzyk prekmurski”, „literacki język porabski". W świetle ustaleń metodologicznych (cf. Дуличенко 1981; Wicherkiewicz 2003) wydaje się zasadne stwierdzenie, że współczesny język prekmurski (prekmurszczyzna) lub też współczesny język porabski (porabszczyzna) to pojęcia nazywające literacki mikrojęzyk prekmurski bądź literacki mikrojęzyk porabski (jeśli dotyczy wyłącznie piśmiennictwa Słoweńców porabskich). Należy mieć świadomość, że jest to język funkcjonujący na peryferiach słoweńszczyzny, przypisany do konkretnego regionu, nieposiadający wykształconej normy i dla którego nie powstają współczesne gramatyki.

Działalność piśmiennicza Słoweńców porabskich sprawia, że prekmurszczyzna (porabszczyzna) jest nadal żywym językiem literackim w tej części Słowiańszczyzny, pomimo że jej rola została znacznie ograniczona w porównaniu do wieków XVIII i XIX. Od początku tworzenia literackiego języka prekmurskiego widoczny był silny wpływ ortografii węgierskiej, która była stosowana do zapisu dźwięków słoweńskich. Pierwsi pisarze posługujący się zasadami ortografii węgierskiej mieli problemy z zapisem wyrazów słowiańskich, dlatego grafia tekstów prekmurskich była niestabilna, stosowana niekonsekwentnie. Znaczna część współcześnie wydawanych tekstów podlega ortografii słoweńskiej - tzw. slovenicy - uwzględniającej znaki diakrytyczne w miejsce dwu- i trójznaków, stosowanych na oznaczenie spirantów.

Główne cechy współczesnej porabszczyzny to: a) stosowanie w piśmie słowenicy (slovenica); b) diakrytyczny znacznik akcentu używany w funkcji znaczeniowo-wyróżniającej (pomenskorazločevalna funkcija); c) długie dyftongi ej i ou/au, oznaczane w piśmie w postaci $\ddot{u}$ i $\ddot{o}$, a samogłoska $u$ zastępująca w grafii zgłoskotwórcze $l$; d) odmiana przymiotników dokonuje się najczęściej według paradygmatu twardego, końcówki -oga, -omu itd. (Zorko 2005: 47). 


\section{Literatura}

Jembrih A., 2005, Izvori za proučavanje književno-jezičnih hrvatsko-slovenskih veza u 16., 17. i 18. stoljeću u istočnoj Štajerskoj i Prekmurju, w: Prekmurska narečna slovstvena ustvarjalnost. Zbiornik mednarodnega znanstvenega srečanja, red. J. Vurginec, Murska Sobota, s. 186-203.

Jesenšek M., 1999, Jezik v prvem prekmurskem časopisu Prijatel, w: Logarjev zbornik, red. Z. Zorko, M. Koletnik, Maribor, s. 327-343.

Jesenšek M., 2000/2001, Stične točke pri oblikovanju slovaškega in prekmurskega knjižnega jezika, „Jezik in slovstvo” nr 7/8, s. 297-304.

Jesenšek M., 2005, The Slovene Language in The Alpine and Panonian Language Area, Kraków.

Just F., 2003, Besede iz Porabja, besede za Porabje. Pregled slovstva pri porabskih Slovencih, Murska Sobota.

Just F., 2009, Zatišja in stišja porabskega literarnega mikrokozmosa, w: Slovenski mikrokozmosi. Medetnični in medkulturni odnosi, red. I. Novak Popov, Ljubljana, s. $163-178$.

Kowalski P., 2009, Słoweńska mniejszość w Republice Wegierskiej, w: Wspótczesna kultura słoweńska i jej źródta, red. Z. Darasz, Warszawa, s. 153-159.

Kozar St. L., 1994, Slomškova Blaže in Nežica v nedeljski šoli in Košičev Zobrisani Szloven i Szlovenka med Mürov i Rábov, w: Košič in njegov čas. Zbornik razprav o Jožefu Košiču, red. Z. Zorko, M. Bajzek, S. Lukača, Budapest, s. 89-95.

Kryzia W., 2008, Słoweński, Słoweńcy, Stowenia. Zarys historii języka i kształtowania się świadomości narodowej, Katowice.

Novak V., 2006, Slovar stare knjižne prekmurščine, Ljubljana.

Oczkowa B., 2006, Chorwaci i ich język. Z dziejów kodyfikacji normy literackiej, Kraków.

Orožen M., 1996, Molitveni obrazci starejših obdobij v osrednjeslovenskem in vzhodnoslovenskem knjižnem jeziku, w: M. Orožen, Poglavja iz zgodovine slovenskega knjižnega jezika. Od Brižinskih spomenikov do Kopitarja, Ljubljana, s. 35-57.

Perger V., 2009, Vloga porabskega narečja pri ohranjanju narodnostne identitete v Porabju na Madžarskem, w: Slovenski mikrokozmosi. Medetnični in medkulturni odnosi, red. I. Novak Popov, Ljubljana, s. 343-356.

Perlin J., 1986, Przedmowa. Sytuacja językowa w Hiszpanii w świetle ogólnych zagadnień socjolingwistyki, w: J.M. Tortosa, Polityka językowa a języki mniejszości, Warszawa, s. 5-23.

Šekli M., 2004, Jezik, knjižni jezik, pokrajinski oz. krajevni knjižni jezik: genetskojezikoslovni in družbenostnojezikoslovni pristop $k$ členjenju jezikovne stvarnosti (na primeru slovenščine), w: Obdobja 22. Metode in zvrsti. Aktualizacija jezikovnozvrstne teorije na slovenskem. Členitev jezikovne resničnosti, red. E. Kržišnik, Ljubljana, s. 41-58.

Sukič M., 2011, Naše novine so 20 lejt stare, „Porabje” nr 8, s. 1. 
Sukič M., 2012, Intervju <http://www.rtvslo.si/odprtikop/intervju/marijana-sukic/>, 18.06.2013.

Vajda-Nagy N., 2011, Spremljanje medijev slovenske manjšine v Porabju, <http:// dk.fdv.uni-lj.si/diplomska/pdfs/vajda-nagy-nikoletta.pdf>, 20.06.2013.

Wicherkiewicz T., 2003, Języki mniejszościowe i regionalne w Europie - problemy typologii, w: Języki mniejszości i języki regionalne, red. E. Wrocławska, J. Zieniukowa, Warszawa, s. 73-78.

Zorko Z., 2005, Prekmursko narečje med Muro in Rabo na vseh jezikovnih ravninah primerjalno z današnjim nadnarečnim prekmurskim knjižnim jezikom, w: Prekmurska narečna slovstvena ustvarjalnost, red. J. Vurginec, Murska Sobota, s. 47-68.

Дуличенко А.Д., 1981, Славянские литературные микроязыки (Bопросы формирования и развития), Таллин.

Дуличенко А.Д., 2003, Языки этнических меньшинств и языки региональные (региолекты): некоторые методологические аспекты, w: Języki mniejszośsi i języki regionalne, red. E. Wrocławska, J. Zieniukowa, Warszawa, s. 27-39. 
